\title{
A vital role for aquatic resources in feeding a hungry world
}

\author{
By K. J. Whittle, Torry Research Station, I 35 Abbey Road, Aberdeen AB9 8DG
}

Aquatic resources for food comprize marine and freshwater fish (and shellfish) and aquatic plants. In the main, natural populations are harvested, with aquaculture increasingly augmenting supplies. The excellent nutritional value of fish (Carpenter, 1980), divided roughly into lean demersal (white fish) and fatty pelagic types is unquestionable. However, there are enormous numbers of potential consumers unaware of the value of fish as food, particularly in the developing world.

\section{Global supplies}

The world fish catch in 1982 was 74.8 Mtonnes live weight, only $0.5 \%$ up on I98I (Food and Agriculture Organization (FAO), I983), and a significantly smaller annual increase than the $2 \%$ typical of the 1970 (Robinson, 1980 ). This is mainly due to the approaching limits of currently-exploited conventional resources and continued over-fishing in some areas. The catch included 8.7 Mtonnes from freshwater sources, but the so-called unconventional resources, usually defined as euphausids, mesopelagic species and oceanic squid, represented less than $1 \%$ of the total. In addition, the total production of aquatic plants, mostly seaweeds, was at least 3 Mtonnes. Some $60 \%$ of the seaweeds and about $70 \%$ of the fish catch (5r.5 Mtonnes) was used directly for food. The catch provided $14 \%$ of the world population's need for animal protein, $4-5 \%$ of the total protein requirements but less than $r \%$ of energy needs. The remainder of the catch was used variously for animal feed, although fish meal now accounts for less than $10 \%$ of total fish trade value compared with about $15 \%$ in the early 1970 s. About $30 \%$ of the world fish catch is thought to be moving into international trade and the catch has grown over the last 25 years.

\section{Importance of fish to developing countries}

In 1982, the developing countries' share of the world catch was nearly $48 \%$ (35.7 Mtonnes), up $2.8 \%$ on 1981 , due largely to increased landings in South America (INFOFISH, 1983 ). In the last 15 years growth has been rapid (particularly in some countries of Asia, Africa and South America), although it has not always benefited the poor, contributing instead to exports to earn foreign exchange. The poor are dependent mainly on cereal-based diets and even a small quantity of fish can be nutritionally important. In many developing countries the poor spend more of their household money on fish than on other protein foods.

Crown copyright reserved. 


\section{Meeting future demand}

Projections of demand are notoriously inaccurate. Robinson (1980) estimated the demand for fish for food by the year 2000 to be 97 Mtonnes, since revised downward to 82 Mtonnes (James, 1983). Maintenance of consumption by an increased population accounted for 19 Mtonnes. Developing countries will account for $90 \%$ of the population increase and demand will be greatest in South-east Asia. If the demand for fish meal remains unchanged, a catch of about ${ }^{2} 0_{4}$ Mtonnes will be needed by the year 2000. Any extension of fish supplies to new groups of consumers not in the current pattern will increase demand.

Superficially, estimates of a potential marine catch of conventional species of 91-105 Mtonnes (NORWAY/FAO, I 983 ) seem almost adequate to satisfy demand up to the year 2000. However, such estimates depend on maximum exploitation of stocks, so the scenario is unrealistic. A shortfall of at least 10 Mtonnes is anticipated which can only be met by using conventional resources to the fullest extent for food.

Losses after harvesting such that the product is unsaleable must be reduced whether due to spoilage of fresh fish, storage losses of frozen fish, pest infestation of cured or dried fish or poor process control of canned fish. Estimated losses due to spoilage are 1.5 Mtonnes or $10 \%$, whereas those occurring in cured fish during drying and storage (FAO, 1981 ; Wood, 1983 ) are 2.7 Mtonnes or $25 \%$ (James, 1983).

Improved efficiency in processing, particularly in developed countries, can make more use of current catches, by reducing waste and increasing the proportion of flesh recovered by greater use of machines which separate more edible flesh from the filleting waste, virtually leaving only skin and bone. In the UK for instance, where we process some 350000 tonnes whole demersal fish per year, the additional flesh yield could be $60000-80000$ tonnes. Not all the problems of using this minced fish material have been solved (NFI, I980; Grantham, I98I), but it can be processed into attractive and successful products with value sufficient to offset processing costs. The quantity of offal left for conversion to fish meal is reduced correspondingly. In theory at least, recovery can be increased further. For example, the Lensfield processes could extract useful protein and phosphate from the bones in deboner waste giving yields of about $24 \%$ and $13 \%$ of the protein and phosphate preparations respectively (J. Wignall, personal communication).

Unexploited stocks of unfamiliar but conventional species still remain in certain areas and, throughout the world, fishing nations continue to explore their use (Chandrashekar et al. 1978; Chen, 198I; Feldheim, 198I; Schwartz, 198I; Anon. 1982; Connell \& Hardy, 1982). Expanded aquaculture for fish and shellfish (especially mussels) could yield a further 30 Mtonnes annually (Pillay, quoted by James, 1983), but space does not permit any detailed consideration here. Further expansion of aquatic supplies for food or feed, perhaps by more than 300 Mtonnes, depends on exploitation of the unconventional resources. 


\section{Conventional resources}

By-catch. Most trawl fisheries generate a by-catch caught incidentally to the target species. In a few cases, such as the plaice caught by the Dutch sole fishery, the by-catch is valuable and is retained and marketed with care. In others, the by-catch has little intrinsic market value and, traditionally, is discarded at sea. This was particularly true of the world shrimp fisheries, some of which are in the coastal waters of the world's poorest countries (for review, see IDRC, I 982). Now, there is some effort to retain at least a percentage of the larger marketable fish which range from 25 to $70 \%$ of the by-catch of mostly demersal fish, but toxic species (up to $15 \%$ ) must be separated out first. The balance is predominantly small fish $(<250 \mathrm{~mm})$.

Estimates of the total by-catch have varied from 3 to 21 Mtonnes but, conservatively, the fisheries could yield 3-5 Mtonnes fish suitable for food provided the fish are kept and landed in good condition. They can be used as fillets, as salted, smoked, dried, pickled or canned fish or even as speciality products. However, for less expensive products, deboned minced fish seems the most versatile and simple raw material recoverable from the smaller fish, provided difficulties in gutting are overcome (Poulter \& Trevino, 1982). Nutritious and tasty products such as fish crisps, noodles, balls, fingers, croquettes, slicing sausages, dried soups and kamaboko-type products have been made, as well as canned products substituting for existing meat products e.g. paté and sausage). A dried, salted mince product sealed in plastic bags had a shelf-life of 4 months at ambient temperature in Guyana, making it ideal for distribution to areas remote from the coast (Stanley, 198I). Development of an inexpensive nutritious and acceptable baby food is an obvious next step.

Ideally, some of the products mentioned are intended to help the poor, but introduction of new product forms to them is no easy task. Experience suggests that product promotion needs to cover a variety of markets and income groups to enable economic manufacture. The economics can be improved by utilizing the by-catch fully, e.g. meeting local needs for meals for feed and fertilizer (by cheap and simple small-scale liquid silage production) and finding markets for items such as shark fins, leather and teeth, fish scales, glues and chitosan.

Small pelagic fish. About 33 Mtonnes small pelagic fish (defined by Lanier, I981) were caught in 1981 (FAO, 1983) and some 14 Mtonnes were converted to fish meal. Even in Japan, only $30 \%$ of the 3.3 Mtonnes sardine caught and $60 \%$ of the I Mtonne mackerel catch was used for food (Suzuki, 1984). According to the FAO ( 1983 ), another $5^{-15}$ Mtonnes are not harvested, mainly by developing countries, because of the lack of suitable catching, handling and processing facilities. Making full use of the existing and potential catches for food is a big challenge for the fish technologist. The fisheries are seasonal, potential catches are heavy and composition varies. The fish are usually small, bony, fragile, easily-spoiled and fatty. Mechanized handling is expensive and the high fat content makes them more susceptible to deterioration and decreases the drying rate. 
Poorly-dried fish are prone to insect infestation. The populations adjacent to these fisheries tend to have low purchasing power, and distribution and marketing systems are poor. High volume, low cost, effective preservation methods are essential to expand the use of these resources for food.

Chilled or refrigerated sea-water storage systems and ice are effective means of chilling fish rapidly after catching. Most of the fish (about $31 \%$ ) are consumed fresh, the remainder being distributed almost equally between canned, frozen and cured products. Nearly 4 Mtonnes are used for a wide variety of high- and low-cost canned products. World production and trade expanded steadily in the last decade and there appear to be continuing good prospects for these products (Lanier, I98I ; Matton, 1982), however, $\mathrm{Da}$ Costa (1980) has concluded that freezing is likely to increase in importance compared with canning. Energy consumption can be reduced in frozen distribution whereas canning may only make a positive contribution if novel low-cost containers are developed. Cold-distribution chains are being introduced to some developing countries but the product is usually too expensive for the poor. Traditional curing is popular in many tropical countries. Although drying, salting and smoking result in large post-harvest losses, the major advantage is low product costs. In extending consumer acceptance, it is worth noting that in Somalia, dried fish was found acceptable to nomadic refugees with no traditions of eating fish.

The introduction of novel processes and products has been directed in large measure at high-income groups. For instance, recently at the Torry Research Station we have developed a generic range of novel, frozen, breaded fatty-fish-portion products composed of an almost endless variety of sauces, flavours and ingredients (Keay, I980), with the intention of increasing home consumption of our substantial under-used pelagic fish resources. In contrast, a much cheaper, yet nutritious and energy-rich minced fish product with a few months shelf-life at $25^{\circ}$ has been developed (L. Talabi and R. Hardy, personal communication). Fatty-fish mince, sometimes with binders or colouring included, was hand-moulded into fillet shapes and cooked in boiling, saturated brine. Most of the fat was retained, the final protein:water value was about 1 : I and the water present was saturated with salt. The product can be smoked and was packed in polyethylene bags. It was suitable for use in fish stews without desalting and was very acceptable to West Africans used to eating fish in stews. The formulation could be altered to suit other traditions. Addition of antioxidant and a mould inhibitor would prolong shelf-life. Fish sauce, popular in South-east Asia, prepared by heavy salting and slow solubilization of the fish, is another relatively cheap and versatile product which could be expanded.

Space does not permit an account of the reasons for the development, expectations, basic misconceptions and failure of fish-protein concentrate (FPC) (see Pariser et al. 1978) except to say that the zeal to remove fat made it an energy-deficient product. However, the less expensive FPC type B, which can contain up to $10 \%$ fat, has been accepted by consumers in limited amounts in food-aid programmes in Africa, the Middle East and Asia (Pariser, 1980). 
The Japanese have developed an alternative form of FPC, Marinbeef (Suzuki, 1981), intended as a meat substitute or extender. Washed minced fish is made slightly alkaline and kneaded to a paste with salt ( $1 \%)$, extruded and denatured and defatted in ethanol. The solvent-free protein is air-dried to a water content of less than $10 \%$ to give a grainy, rice-like, fat-free product of $90 \%$ protein with a shelf-life of several years under dry conditions at $20-30^{\circ}$. Marinbeef is reconstituted in water before cooking. A plant is due to become operational this year in Peru with an annual capacity of 700 tonnes product (Suzuki, 1984). A number of other fish protein powders have been developed recently in Japan, variously based on sardine, prawn and cuttlefish.

\section{Unconventional resources}

Euphausids. The euphausids, abundant in the Antarctic Ocean, are small (usually $<50 \mathrm{~mm}$ ), shrimp-like animals comprising roo or more species referred to as krill, of which Euphausia superba dana is the species of major commercial interest. The fishery occurs during the Antarctic summer, daily catch rates being as high at 20-1 30 tonnes, and probably is best fished by large factory trawlers. Estimates of abundance vary but the limited information available suggests a potential catch of 50-200 Mtonnes (Karnicki, 1982; James, 1983). In 1981, the catch was 45000 tonnes (FAO, 1983 ), led by the USSR (about $90 \%$ ), followed by Japan $(8 \%)$ and Poland $(<\mathrm{r} \%)$. Probably about $99 \%$ of the Soviet catch was converted to meal for animal feed.

The chemical composition of krill meat is similar to familiar crustacea such as shrimp and lobster, but lower in protein and higher in fat, and is well balanced for human nutrition; chitin in whole raw krill is about $1 \%$. Krill was reported to have a high fluoride concentration. Subsequently, this was shown to be present in the shell but is thought to migrate from shell to meat during chill storage.

Since 1960 research into the use of krill for food was begun first by the USSR and then by Japan, West Germany, Poland and Chile. The Torry Research Station carried out a small research programme on some aspects (1976-1978) in collaboration with West Germany. After recently feeding on phytoplankton, krill is unsuitable for food because of the dark green discoloration and strong grassy flavour. The most serious processing problems are that it is very perishable and very delicate to handle. Ideally, it should be processed for food within $3^{-4} \mathrm{~h}$ of catching or, for conversion to meal, within 8-12 h. Experts disagree about whether holding time before processing for food can be extended by storage in chilled or refrigerated sea-water. Soon after catching, a preliminary cook $^{2}-5 \mathrm{~min}$ at $90-95^{\circ}$ ) arrests deterioration during frozen storage by inhibiting enzyme action.

Products researched include frozen whole krill, frozen peeled meat, soups, canned products, squid stuffed with krill, krill balls, surimi derived from krill, protein concentrates and paste. In the USSR the paste is used as a constituent of other products such as salads, pate and dumplings. Recovery of tail meat, for which yield is a little less than shrimp, is one of the most promising products. If such products can be marketed successfully and particularly if surimi production is 
both practically and economically feasible, a potentially large food supply will be available. However, to be economic, processes have to be envisaged on a large scale; one reason why most of the USSR catch is converted to meal. Shipboard processing lines for producing paste, capable of processing 50 tonnes raw material daily, have been developed in the USSR. It is believed that some 2000 tonnes are produced annually (Karnicki, I982). Processing and products have been reviewed in detail recently (Sikorski, I 980 ; Suzuki, 1981).

Mesopelagic fish. Mesopelagic fish, often called lantern fish, are small, bony and usually oily fish occurring worldwide (for review, see Gjøsaeter \& Kawaguchi, I 980 ). Global biomass is estimated to be 950 Mtonnes and density in the oceans is generally low. However, there are coastal areas in sub-tropical and tropical seas where there is good evidence of large stocks, e.g. the Arabian Sea, West Africa and South America, and the total stock in the Indian Ocean is thought to be 35 I Mtonnes.

Varying quantities of mesopelagic fish are caught incidentally in the anchovy purse seine fishery off South Africa (Newman, 1977) and by the USSR off West Africa, and are converted to fish meal and oil and to fish silage. However, some species have high oil contents and high wax-ester concentrations in the oil (Nevenzel et al. I 969) which produce side-effects when given as a high proportion of the diet to animals (Mori et al. 1966). Haque et al. ( $198 \mathrm{I}$ ) carried out successful short-term feeding trials on a limited number of chicks with a few samples of fish meal prepared from lantern fish from the Arabian Sea with low wax-ester contents in the lipids: proximate analysis of the fish meal was within the range of high-quality capelin meal and digestibility for the chicks was slightly lower. Further research is required before firm conclusions can be drawn on nutritive value and possible toxic effects; this work is essential before processing and marketing can be developed on any scale. Nevertheless, in Japan, some species are caught and consumed locally (Kawaguchi \& Shimizu, I 978).

Effective fishing techniques are needed to develop a directed fishery. More information is required about the behaviour of the fish and variability in potential yield. Nevertheless, in the longer term, given adequate investment, mesopelagic stocks could make a significant contribution to supplies for industrial needs where the exploitable stocks are in areas where demand will be high.

Cephalopods. The cephalopods, comprising cuttlefish, octopus and squid, are distributed worldwide and have been part of man's diet since early times, particularly in Oriental and Mediterranean countries. Elsewhere, they are regarded as unconventional. Cephalopods became prominent in the world catch after World War II as the Japanese fishing industry expanded. Over the last decade, the catch increased by about $50 \%$ and world trade quadrupled (Hotta, 1973), partly due to developing countries increasing export earnings and supplementing domestic food supplies. In $198 \mathrm{I}$, over I 4 Mtonnes were caught (FAO, I983), of which Japan took about $40 \%$ comprising some $75 \%$ squid and equal proportions of octopus and cuttlefish. The catch yielded about 43000 tonnes product. Nearly $90 \%$ was frozen, to which developing countries contributed i $\%$ (INFOFISH, I 983). 
Despite fragmentary resource information, it is clear that cephalopods, especially squid, remain under-exploited, probably contributing no more than about $20 \%$ of the potential for all coastal regions. In addition, it has been suggested that some twenty species of the larger oceanic squid could yield I 50-500 Mtonnes/year (Voss, I973; James, 1983). Oceanic distribution is probably quite dispersed, but fishable aggregations may occur where water masses mix along the major equatorial current systems. Efficient catching techniques must be developed to exploit this resource but they could be prohibitively expensive for developing countries.

Japan and other Oriental countries consume about $70 \%$ of the world catch of cephalopods. Mediterranean countries are important markets and there is growing interest in northern Europe and North America. World demand from existing markets in developed countries and from developing countries where cephalopods are known is expected to increase by over $50 \%$ to 2 Mtonnes/year by 1990 (Hotta, 1973), well within the capacity of the coastal fisheries. In other countries there are opportunities to develop new markets, particularly for squid, in the form of convenient, manufactured products, but without strong flavours.

The edible parts of squid are $60-80 \%$ by weight, depending on size and species. The protein content is $16-20 \%$, similar in quality to that of fish, and the energy content is about $3.5 \mathrm{MJ}\left(85^{\circ} \mathrm{kcal}\right) / \mathrm{kg}$ raw flesh. The beak and pen, which are removed in preparation, represent the only skeletal parts. Squid spoils rapidly if it is not handled properly and preparation is labour intensive. It is susceptible to physical damage with consequent loss of value and it is not easy to grade and process mechanically. Nevertheless, equipment is available for various aspects of mechanical processing (Sheehy \& Vik, 1980 ) and new developments (Singh \& Brown, 1980) are in progress (NEFDF, 1982). Skinning by mechanical or chemical action or by enhanced enzyme action (Hempel, 1983) is possible. New, attractive consumer products are being developed in America and Europe including soups, frozen portions for home or catering, pasta products and novel machine-formed products based on minced squid.

Production of protein concentrates by various methods such as spray-drying and extraction have been investigated. Solvent extraction (Sonu, 1974) produced an odourless product with no functionality. Salt extraction or alkaline extraction with iso-electric precipitation gave variable composition and characteristics (Kahn et al. 1974, 1975). The iso-electric precipitates were the most acceptable, often being comparable with a commercial soya-bean protein (Tong et al. 1975) but the concentrates retained some of the characteristic squid aroma, a serious limitation to their potential use. Small fish and waste from processing can be converted to meal for animal feed.

Aquatic plants. In 1981 , the total harvest of aquatic plants, mostly macroalgae or seaweeds, was about 3 Mtonnes wet weight; the harvest increased by $50 \%$ during the 1970s. Japan, China, Korea, Chile and Norway each harvested over 100000 tonnes. Seaweeds are used directly for food, for extraction of hydrocolloids and for animal feed or fertilizer. The red and brown seaweeds are the most 
important for food $(59 \%)$ and industrial $(4 \%)$ purposes. Brown seaweeds are the most abundant, particularly in northern waters, e.g. around the British Isles $90 \%$ of seaweeds are the brown species Laminaria and Ascophyllum, representing a stock of well over io Mtonnes. In contrast, the red seaweeds are the most diverse, and probably the most valuable as food sources.

Certain species produce toxins, but Becker (198I) lists some fifty species suitable for consumption, many already being used as food or feed. The value of algae as sources of major nutrients is very limited. Nevertheless, some contain high concentrations of good-quality protein and could provide a good future protein source provided inexpensive processing methods can be developed. They are reputed to be a valuable source of vitamins such as $A$, thiamin, riboflavin, niacin and $C$, and of minerals such as calcium, iron and iodine (Matsuzaki \& Iwamura, I $98 \mathrm{I}$ ). With a few exceptions, use for food is restricted primarily to Asian countries (McHugh \& Lanier, 1983) where a variety of seaweeds has been enjoyed for thousands of years; at least thirty-five species of seaweed are used already in Asia (Rabanal \& Trono, 1983) and even microscopic forms are eaten in Chad and Mexico. Some 100 varieties of seaweed food products are available in Japan. There the seaweed harvest is $6-7 \%$ of the fish catch and contributes about $5 \mathrm{~g}$ dry weight to the average daily diet but supplies less than $3 \%$ of protein requirements. About I 00000 tonnes dry weight are produced collectively by Indonesia, the Philippines and Thailand consisting mainly of the red seaweeds Gracilaria and Eucheuma, much being used for food. Japan, China and Korea collectively consume 400000 tonnes dry weight and most trade is between these countries. The principal foods are: kombu (dried Laminaria sp.), used as a vegetable, stock, seasoning or as a snack; wakame (dried and salted Undaria), used in soup; laver (dried Porphyra), used in a variety of dishes. Laver contains much more protein $(25-35 \%)$ than brown seaweed products $(8-15 \%)$ and is a superior food but more expensive. Fresh seaweeds, including green varieties, are particularly attractive in salads and can be cooked as a vegetable. In the rest of the world, seaweeds are unfamiliar as food although extracts are widely used in the food industry (for reviews, see Okazaki, 1971; Naylor, 1976; Chapman, 1980).

Naylor (1976) estimated that the potential global seaweed harvest could be 17 Mtonnes but exploitation at half this level is more realistic for economic reasons. The greatest potential lies in the Pacific coastal regions and in expanding production of edible species in Asian countries with suitable marine environments near existing markets.

Mariculture by planting cuttings of the vegetative parts of selected species in prepared and segregated tidal areas or in partly-enclosed semi-tidal or totally-enclosed ponds is carried out in Korea, the Philippines and Taiwan. Culture of red seaweeds is nutritionally and economically more beneficial and the production methods are suitable for small-scale developments to benefit poor coastal communities. It might be possible to expand the use of seaweeds for food more widely in the world (Bruce, 1983 ). However, supplies need to be stablized in relation to demand for the respective uses (Rabanal \& Trono, r 983). 
Various proposals have been made for large-scale axenic culture of microalgae to produce non-toxic protein concentrates or algal powders for animal feed and food purposes, comparable nutritionally with other plant materials such as soya-bean protein (e.g. Jaleel \& Soeder, 1973; Baron \& Clement, 1974).

\section{Conclusions}

Over the next I 5 years, conventional fishery resources could just about keep pace with projected demand based on current consumption patterns, provided post-harvest losses and the proportion of the catch converted to meal are reduced, and efficiency of processing and supplies from aquaculture are increased. Most demand will come from the developing world. This may increase still further as inexpensive, acceptable, stable products are introduced which can be distributed more easily from the coast to inland communities who do not consume fish at present.

Increasing exploitation of the unconventional resources is essential to extend aquatic resources for food to a wider sector of the world's population and meet demand for industrial purposes, although the practical and economic problems remain large. Table I summarizes the picture of current and potential supplies of aquatic resources.

It seems likely that progress will occur slowly in most of the areas where supplies can be expanded except where economics dictate otherwise, for example, more efficient processing. Utilization of the pelagic catch is the greatest challenge to the fish technologist but exploitation of oceanic squid seems the most intractable

Table I. Summary of current and potential global aquatic resources*

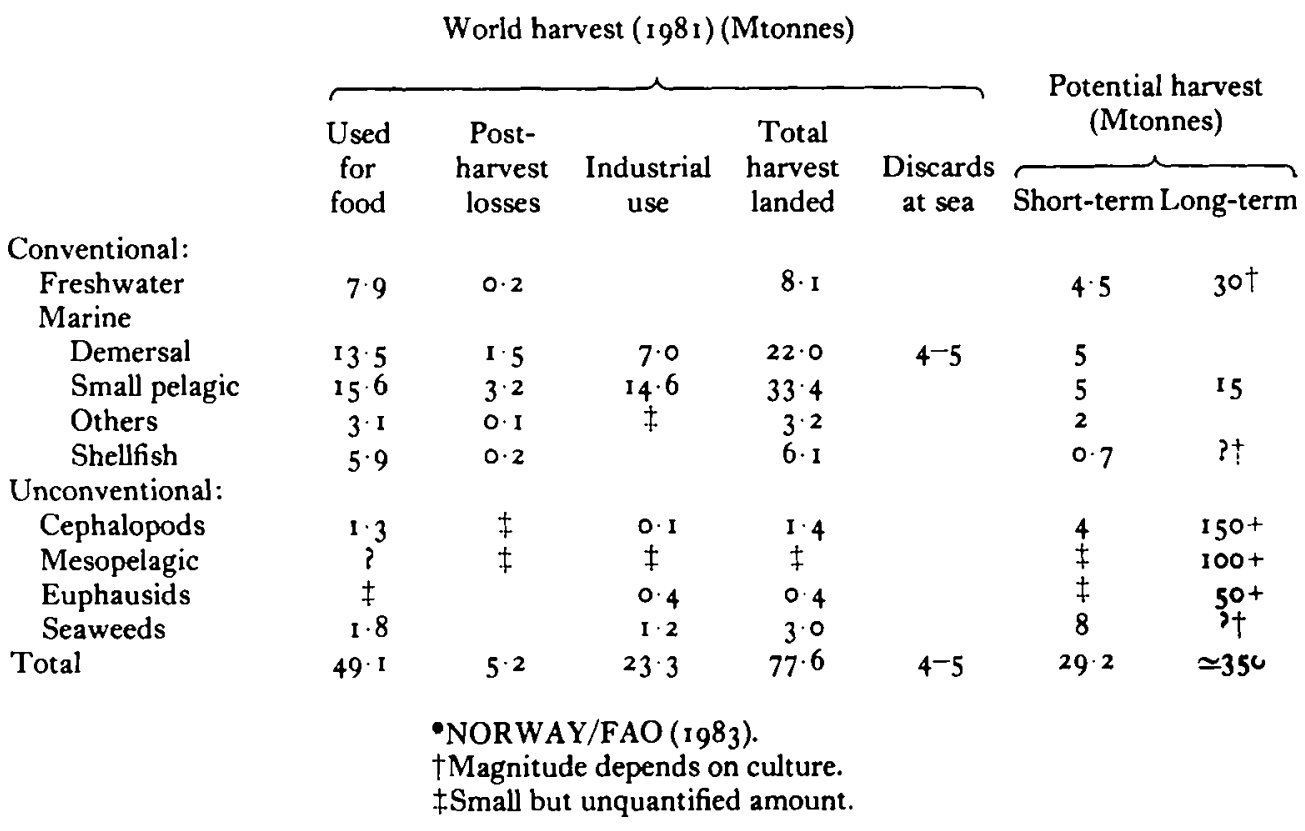


overall problem of the possibilities discussed. The annual production of phytoplankton and zooplankton in the important fishing areas of the world is of the order of $10^{5}$ Mtonnes but the possibilities of either being harvested for food are very speculative.

\section{REFERENCES}

Anon. (1982). Food Processing 43, 22-28.

Baron, C. C. \& Clement, G. (1974). Proceedings IVth International Congress of Food Science and Technology 8A, 30-32.

Becker, W. (1981). In Food From the Sea, pp. 135-161 [H. Noelle, editor]. Berlin: SpringerVerlag.

Bruce, C. (1983). FAO INFOFISH Marketing Digest 4, 27-28.

Carpenter, K. J. (1980). In Advances in Fish Science and Technology, pp. 124-130 [J. J. Connell, editor]. Farnham: Fishing News Books Ltd.

Chandrashekar, T. C., Rudrasetty, T. M., Lakshman-Reddy, P. T. \& Aswathnarayana, C. (1978). Fishery Technology $15,125^{-1} 28$.

Chapman, V. J. (1980). Seaweeds and Their Uses, 3rd ed. London: Chapman and Hall.

Chen, H. P. (1981). Refrigeration Science and Technology 4, 55 I-557.

Connell, J. J. \& Hardy, R. (1982). Trends in Fish Utilization. Farnham: Fishing News Books Ltd.

Da Costa, A. A. (I980). Fish Utilization and Trends in Latin America. Report of Round Table Discussions on Non-traditional Fish Products for Massive Human Consumption. Washington, DC: IDB.

FAO (1981). The Prevention of Losses in Cured Fish. FAO Fisheries Technical Paper no. 219. Rome: Food and Agriculture Organization.

FAO (1983). 1981 Yearbook of Fishery Statistics, vol. 52. Rome: Food and Agriculture Organization.

Feldheim, W. (198I). In Food From the Sea, pp. 77-84 [H. Noelle, editor]. Berlin: SpringerVerlag.

Gjøsaeter, J. \& Kawaguchi, K. (1980). A Review of the World Resources of Me'sopelagic Fish. FAO Fisheries Technical Paper no. I 93. Rome: Food and Agriculture Organization.

Grantham, G. J. (1981). Minced Fish Technology: A Review. FAO Fisheries Technical Paper no. 216 . Rome: Food and Agriculture Organization.

Haque, A., Pettersen, J., Larsen, T. \& Opstvedt, J. (1981). Fournal of the Science of Food and Agriculture 32, 6I-70.

Hempel, E. (1983). FAO INFOFISH Marketing Digest 4, 30-31.

Hotta, M. (1 973). ADB/FAO INFOFISH Market Report 4, I-53.

IDRC (1982). Fish By-catch. Bonus from the Sea. Ottawa: International Development Research Centre and Rome: Food and Agriculture Organization.

INFOFISH ( 1983 ). FAO INFOFISH Marketing Digest 5, I-48 (statistical supplement).

Jaleel, S. A. \& Soeder, C. J. (1973). Indiun Food Packer 27(1), 45-57.

James, D. (1983). Proceedings 6 th World Congress of Food Science and Technology.

Kahn, I. N., Berk, Z., Pariser, E. R., Goldblith, S. A. \& Flink, J. M. (1974). Journal of Food Science 39, 592-595.

Kahn, L. N., Berk, Z., Tong, S. D., Pariser, E. R., Flink, J. M. \& Goldblith, S. A. (1975). Lebensmittel-Wissenschaft Technologie 8, 64-69.

Karnicki, Z. S. (1982). Fishing Nezw International 2 1(6), 28.

Kawaguchi, K. \& Shimizu, H. (1978). Bulletin of the Ocean Research Institute of the University of Tokyo 10, $\mathrm{I}-145$.

Keay, J. N. (1980). In Advances in Fish Science and Technology, pp. 275-278 [J. J. Connell, editor]. Farnham: Fishing News Books Ltd.

Lanier, B. V. (1981). The World Supply and Demand Picture for Canned Small Pelagic Fish. FAO Fisheries Technical Paper no. 220. Rome: Food and Agriculture Organization.

McHugh, D. G. \& Lanier, B. V. (1983). ADB/FAO INFOFISH Market Report 6, 30. 
Matsuzaki, S. \& Iwamura, K. (1981). In Food From the Sea, pp. 162-185. [H. Noelle, editor]. Berlin: Springer-Verlag.

Matton, E. (1982). Markets for Frozen Small Pelogic Fish. FAO Fisheries Technical Paper no. 221. Rome: Food and Agriculture Organization.

Mori, M., Saito, T., Nakanishi, Y., Miyazawa, K. \& Hashimoto, Y. (1966). Bulletin of the fapanese Society of Fisheries 32, $137^{-1} 45$.

Naylor, J. (1976). Production, Trade and Utilization of Seaweeds and Seaweed Products. FAO Fisheries Technical Paper no. I 59. Rome: Food and Agriculture Organization.

NEFDF (1982). Proceedings of the International Squid Symposium. New York: New England Fisheries Development Foundation UNIPUB.

Nevenzel, J. C., Rodecker, W., Robinson, J. S. \& Kayama, M. (1969). Comparative Biochemistry and Physiology 31, 25-36.

Newman, G. (1977). The Living Marine Resources of the Southeast Atlantic. FAO Fisheries Technical Paper no. 1 78. Rome: Food and Agriculture Organization.

NFI (1980). In Proceedings of the Third National Technical Seminar on Mechanical Recovery and Utilization of Fish Flesh, Raleigh, North Carolina. [R. E. Martin, editor]. Washington, DC: National Fisheries Institute.

NORWAY/FAO (1983). The Potential of Fisheries in Alleviating Undernutrition. FAO Fisheries Circular no. 76r. Rome: Food and Agriculture Organization.

Okazaki, A. (1971). Seaweeds and Their Uses in fapan. Tokyo: Tokai University Press.

Pariser, E. R. (1980). Fish Protein Concentrates Types $A$ \& B. Problems and Promises. Report of Round Table Discussions on Non-traditional Fish Products for Massive Human Consumption, Washington, DC: IDB.

Pariser, E. R., Wallerstein, M. B. Corkery, C. J. \& Brown, N. L. (1978). Fish Protein Concentrate: Panacea for Protein Malnutrition. Cambridge: The MIT Press.

Poulter, N. H. \& Trevino, J. E. (1982). Fish By-catch. Bonus from the Sea, pp. 77-80. Ottawa: International Development Research Centre and Rome: Food and Agriculture Organization.

Rabanal, H. R. \& Trono, G. C. (1983). FAO INFOFISH Marketing Digest 4, I9-22.

Robinson, M. A. (1980). Marine Policy 4, 19-32.

Schwartz, J. W. (1981). Polish Maritime News 24, (275/276), 29-31.

Sheehy, D. J. \& Vik, S. F. (1980). Marine Fisheries Review 42, 85-92.

Sikorski, Z. E., Bykowski, P. \& Knyszewski, J. (1980). In Food Process Engineering, vol. 1, pp. 845-855 [P. Linko, Y. Malkki, J. Olkku and J. Larinkari, editors]. London: Applied Science Publishers Ltd.

Singh, R. P. \& Brown, D. E. (1980). Marine Fisheries Review 42, 77-84.

Sonu, S. C. (1974). Dissertation Abstracts International B34, 4433.

Stanley, B. (1981). Fishing News International 20(10), 104-105.

Suzuki, T. (I98I). Fish and Krill Protein. Processing Technology. London: Applied Science Publishers Ltd.

Suzuki, T. (1984). FAO INFOFISH Marketing Digest 1, 34-36.

Tong, S. D., Flink, J. M. \& Goldblith, S. A. (1975). LebensmittelWissenschaft Technologie 8, $70-74$.

Voss, G. L. (1973). Cephalopod Resources of the World. FAO Fisheries Circular no. 149. Rome: Food and Agriculture Organization.

Wood, C. D. (1983). In The Production and Storage of Dried Fish. FAO Fisheries Report no. 279, pp. I 72-184. [D. James, editor]. Rome: Food and Agriculture Organization. 